\title{
A Comparative Study between the Performance of Iranian High and Low Critical Thinkers on Different Types of Reading Comprehension Questions
}

\author{
Samira Mohammadi Forood \\ Department of English Language, Science and Research Branch, Islamic Azad University, Tehran, Iran \\ Ali Akbar Khomeijani Farahani \\ College of Foreign Languages and Literatures, University of Tehran, Iran
}

\begin{abstract}
The present study aimed to find out whether there is any significant difference between the performances of high and low critical thinkers on factual, referential, and inferential reading comprehension questions. For this purpose, 42 learners were selected as the homogenized group. Afterwards, the Farsi version of Watson- Glaser Critical Thinking Appraisal (1980) (Form A) was administered to the participants and they were then assigned to two groups of high and low critical thinkers. Both groups were provided with a reading comprehension test including factual, referential, and inferential questions. The obtained data was analyzed via 16th version of the Statistical Package for Social Sciences (SPSS). The Findings revealed that (a) there is a significant difference between high and low critical thinkers on their performance on factual reading comprehension questions, (b) there is a significant difference between high and low critical thinkers on their performance on referential reading comprehension questions, and (c) there is a significant difference between high and low critical thinkers on their performance on inferential reading comprehension questions. The study has some implications for language teachers, text book writers, and test designers.
\end{abstract}

Index Terms - critical thinking ability, factual questions, referential questions, inferential questions

\section{INTRODUCTION}

Many studies have been conducted in the domain of critical thinking to remind the learners and teachers about its significant role in education. Life without having a critical view toward issues turns out to be something repetitive and human beings running such a life turn out to be mere followers.

Critically thinking empowers people to look at everything from a different angle. This is what we need to do in our everyday life. Halpern (2003) also believes critical thinking is an everyday activity and is a vital necessity for the citizens of current century. Critical thinking enables individuals to tackle problems, penetrate into them, analyze them and finally find solutions. These abilities have helped societies to develop an age of technology which was one of the ambitions and dreams of their ancestors (Bassick, 2008).

Although there is a debate among scholars about the teachability of critical thinking, many believe that its strategies should be taught and practiced. Educational organizations and teachers all should do their best to provide opportunities in which learners can practice critical thinking and enable them to apply it to their real life situations. Many researchers such as Spolsky (1998) claim the more critical the learners, the more they are successful not only in their second or foreign language learning but also in other aspects of their lives.

Experts believe that inference, analysis, synthesis, and evaluation are "at the very core of critical thinking" (Facione, 1992, p.5). In fact, these mental skills are also employed in reading comprehension (Grabe, 1991). So, reading comprehension with its various thinking processes seems to have the potentiality for paving the way for applying critical thinking strategies.

According to Bloom (1956), comprehension involves various levels. On the basis of these different levels teachers can create different types of questions. This study aimed to explore whether the ability of thinking critically can help learners in answering different types of reading comprehension questions. Therefore, the following research questions were raised:

1- Is there any significant difference between high and low critical thinkers on their performance on factual reading comprehension questions?

2- Is there any significant difference between high and low critical thinkers on their performance on referential reading comprehension questions? 
3- Is there any significant difference between high and low critical thinkers on their performance on inferential reading comprehension questions?

Concerning the foresaid research questions, the following null hypotheses were formulated:

1- There is no significant difference between high and low critical thinkers on their performance on factual reading comprehension questions.

2- There is no significant difference between high and low critical thinkers on their performance on referential reading comprehension questions.

3- There is no significant difference between high and low critical thinkers on their performance on inferential reading comprehension questions.

\section{LITERATURE REVIEW}

\section{A. Critical Thinking}

Talking about a good educational setting without regarding the notion of critical thinking is impossible. This concept is not newly developed. From centuries ago, human beings came to this conclusion that thinking critically is a necessity and from that time on everybody is encouraged to be a critical thinker. It also became one of the major responsibilities of teachers and material developers to provide the opportunities for learners to practice critical thinking.

Over 2500 years ago, through probing questions, Socrates found out that when challenged, many people are unable of justification by reasoning and "they often display confusion and irrational thought when attempt to justify their knowledge" (Paul, Elder, \& Bartell, 1997).

The concept of critical thinking has developed throughout centuries and various definitions have been proposed, therefore, "there is no consensus on a definition of critical thinking" (Fasko, 2003, p.8), and a single definition is not widely accepted (Halonen, 1995). Norris and Ennis (1989) terms critical thinking as "reasonable and reflective thinking that is focused upon deciding what to believe and do" (p.3). Similarly, Halpern (2003) calls it as "the use of those cognitive skills or strategies that increases the probability of a desirable outcome, thinking that is purposeful, reasoned, and goal oriented" (p.6).

Glaser (1941, cited in Bassick, 2008) believes that the following abilities are essential and required for the process of critical thinking:

- recognizing problems;

- finding workable means for meeting those problems;

- gathering information;

- recognizing unstated assumptions and values;

- comprehending and using language with accuracy, clarity, and discrimination;

- interpreting evidence;

- appraising evidence and evaluating statements;

- recognizing the existence of logical relationships between propositions;

- drawing warranted conclusions and generalizations;

- testing generalizations and conclusions;

- reconstructing one's pattern of belief on the basis of wider experience;

- rendering accurate judgments about specific things and qualities in everyday life.

\section{B. Levels of Comprehension}

At the early years of L2 studies, reading was considered as a passive skill and the bottom-up view toward the reading process was very trendy (Carrell, Devine \& Eskey, 1988). So, learners' problems in reading comprehension were attributed to decoding problems (Rivers, 1968). Later on, according to Carrell (1983), the top-down view replaced the bottom-up approach. But recently the idea of interactive model in reading comprehension involving both top-down and bottom-up processes is acknowledged (Eskey \& Grabe, 1988). The interaction between the reader and the text happens through content schemata, formal schemata, and abstract schemata. The comprehension concept, therefore, involves different levels of mental processing (Grabe \& Stoller, 2002; Nassaji, 2002; Pardo, 2004) which results in different comprehension levels (Erten \& Karakas, 2007). Various taxonomies (Barrett, 1972; Bloom, 1956; Herber, 1978; Irwin, 1986) have studied these levels. Taking these taxonomies into consideration, teachers can define their teaching goals and decide about the cognitive complexity of the questions they ask.

\section{Typology of Comprehension Questions}

One of the most common ways of testing reading comprehension is designing a number of comprehension questions which can be used as pre-reading, while-reading, and post-reading activities. Teachers or material developers can help the students to achieve different levels of comprehension through well-designed exercises and tests. Although some teachers may use paraphrasing or summary writing as their reading methodology, Lehnert (1977) proposes that "the ability to answer questions about a message is a better index of understanding than summarizing or paraphrasing" (p. 70). 
Reading comprehension questions are classified into different categories based on their forms and functions. Widdowson (1983) identifies four types of questions with reference to form: (a) wh-questions, (b) polar (yes/no) questions, (c) true-false questions, (d) multiple-choice questions. In addition to the various forms that comprehension questions take, they may also be identified based on their functions:

- Use and usage reference questions (Widdowson, 1979);

- Macro and micro questions (Cohen \& Fine, 1978);

- Higher and lower order questions (Been, 1975; Watts \& Anderson, 1971);

- Textually explicit, textually implicit, and scriptally implicit questions ( Pearson \& Johnson, 1978);

- Factual, referential, and inferential questions (Farhady, 1998).

\section{Methodology}

The study followed a descriptive, ex post facto design. The researcher asked 60 Iranian sophomores, studying English Translation and Teaching English as a Foreign Language at Roudehen Islamic Azad University, to participate in this investigation. Their ages ranged from 18 to 25, with a mean of 19.92. This sample included 38 females and 22 males who voluntarily accepted to take the test. In order to ensure their homogeneity vis-à-vis their language proficiency, a piloted TOEFL test (ETS, January 2004) was administered. The Cronbach's alpha application showed the reliability of 0.88 . This test comprised of two sections: (a) structure and written expression with 40 items, and (b) reading comprehension with 50 items. The allotted time to take the test was 80 minutes, and the scoring was estimated out of 90. The listening section, not being the focus of the present study, was deliberately omitted for practical reasons. Based on the obtained scores, those learners with a score falling within one standard deviation above and below the mean $(M=65.45, S D=9.33)$ were selected. Finally, 27 females and 15 males $(N=42)$ with the scores between 56 and 75 formed the homogenized group. In the following session, the homogenized group was given Watson-Glaser Critical Thinking Appraisal Test (1980) (Form A). The researcher used the Farsi version of the test, translated by Faravani (2006), of which the reported reliability is $0.85(\alpha=0.85)$. The test had 80 items and five subtests: (a) inference, (b) recognizing unstated assumptions, (c) deduction, (d) interpretation, and (e) evaluation of arguments. According to Watson and Glaser (1980), the test-retest reliability of this test has been $0.81(\mathrm{r}=0.81)$. It was completed in 60 minutes and the scoring was estimated out of 80 . Taking the mean score $(M=65.23)$ into consideration, the students were divided into two groups of high and low critical thinkers. Those who scored 65 and above formed high critical thinkers group (23 participants) and the rest (19 participants) were defined as low critical thinkers. At the next step, in another session, a piloted reading comprehension test consisting of 6 passages followed by an equal number of factual, referential, and inferential questions was administered in both groups of high and low critical thinkers. The recommended time for the examinees to answer the 45 multiple choice items of this test was 55 minutes and scoring was calculated out of 45 . Since the purpose of the test was to check their comprehension ability, they were supposed to answer based on what they understood from the passages and were not allowed to consult their dictionaries. The following is the description of the procedure for piloting reading comprehension test.

Initially, the readability of each of the reading comprehension passages in the TOEFL test was calculated by making use of the "Fog index Formula". As it is demonstrated in "TABLE I", the average readability of TOEFL passages was 15.8 .

TABLE I.

THE READABILITY OF TOEFL PASSAGES

\begin{tabular}{|l|l|}
\hline Passage & Degree of Readability \\
\hline Passage 1 & 18.7 \\
\hline Passage 2 & 12.4 \\
\hline Passage 3 & 14.2 \\
\hline Passage 4 & 18.4 \\
\hline Passage 5 & 15.3 \\
\hline $\mathrm{M}=15.8$ & \\
\hline
\end{tabular}

Accordingly, the researcher started to develop passages with similar readability indices to TOEFL passages. (TABLE II).

TABLE II.

THE READABILITY OF DEVELOPED PASSAGES

\begin{tabular}{|l|l|}
\hline Passage & Degree of Readability \\
\hline Passage 1 & 19.1 \\
\hline Passage 2 & 14.2 \\
\hline Passage 3 & 17.6 \\
\hline Passage 4 & 13.1 \\
\hline Passage 5 & 17.8 \\
\hline Passage 6 & 10.8 \\
\hline $\mathrm{M}=15.4$ & \\
\hline
\end{tabular}


Afterwards, a test with 6 passages and 57 multiple choice questions from factual, referential, and inferential type was piloted among 30 learners. The results of piloting showed that the test enjoyed an acceptable level of reliability ( $\alpha=0.94)$. Based on the results of calculating item facility and item discrimination, 12 items were omitted. The correlation coefficient of 0.72 between the results of the reading comprehension of an original TOEFL test and the developed comprehension test proved that the test is valid enough to be used in this study.

\section{Results}

\section{A. Testing the First Hypothesis}

In order to test the first hypothesis, i.e." there is no significant difference between high and low critical thinkers on their performance on factual reading comprehension questions", an independent samples t-test was utilized to compare the performances of two groups on factual questions. TABLE III displays the descriptive statistics of both groups' performances on factual questions. The mean scores of high and low critical thinkers on factual questions are 12.08 and 10.21 , respectively. It appears that high critical thinkers have performed moderately better on factual questions.

TABLE III.

DESCRIPTIVE STATISTICS OF FACTUAL QUESTIONS SCORES

\begin{tabular}{|l|l|l|l|l|l|l|}
\hline \multirow{2}{*}{ Group } & Mean & Std. Deviation & \multicolumn{2}{l|}{ Skewness } \\
\cline { 2 - 6 } & Statistic & Std. Error & & Statistics & Std. Error & Ratio \\
\hline High Critical Thinkers & 12.08 & 0.42 & 2.02 & -0.23 & 0.48 \\
\hline Low Critical Thinkers & 10.21 & 0.42 & 1.87 & 0.11 & -0.47 \\
\hline
\end{tabular}

According to the above table, the skewness ratio values in high and low critical thinkers $(-0.47,0.21)$ both fall within the acceptable range of \pm 1.96 . Therefore, both sets of scores were normally distributed and running a $t$-test was legitimized. TABLE IV displays the results of the independent samples t-test.

TABLE IV.

T-TEST ON THE FACTUAL QUESTIONS SCORES OF THE HIGH AND LOW CRITICAL THINKERS

\begin{tabular}{|c|c|c|c|c|c|c|c|}
\hline & \multicolumn{2}{|c|}{ Levene's Test for Equality of Variances } & \multicolumn{5}{|c|}{ t-test for Equality of Means } \\
\hline & $\mathrm{F}$ & Sig. & $\mathrm{t}$ & df & Sig. (2-tailed) & Mean Difference & Std. Error Difference \\
\hline Equal variances assumed & 0.375 & 0.544 & 3.095 & 40 & 0.004 & 1.87643 & 0.60629 \\
\hline Equal variances not assumed & & & 3.118 & 39.429 & 0.003 & 1.87643 & 0.60183 \\
\hline
\end{tabular}

The two groups enjoyed homogeneity of variances (Levene's $\mathrm{F}=0.375, p=0.544>0.05$ ). Since the probability associated with the $\mathrm{t}$-value $(\mathrm{t}=3.095, \mathrm{df}=40, p=0.004<0.05)$ is lower that the significance level of 0.05 , the null hypothesis was rejected. Therefore, there is a significant difference between the mean scores of high and low critical thinkers on their performance on factual reading comprehension questions. One more point important to be mentioned here is the effect size as "an indication of the strength of one's findings"(Mackey \& Gass, 2005, p. 282). The effect size is computed by Cohen's $d$ and $r$ using the t-value and df. Cohen's $d$ is 0.97 yielding $r$ value of 0.43 . According to Cohen's standards, it is interpreted as a large effect and could be considered large for the purpose of generalization.

\section{B. Testing the Second Hypothesis}

In order to test the second hypothesis, i.e. "there is no significant difference between high and low critical thinkers on their performance on referential reading comprehension questions", an independent samples t-test was run to compare high and low critical thinkers on referential questions performance. According to TABLE V, scores of referential questions in high and low critical thinkers with the skewness ratio of 0.85 and 0.76 are distributed normally and therefore, running a t-test was legitimate.

TABLE V.

DESCRIPTIVE STATISTICS OF REFERENTIAL QUESTIONS SCORES

\begin{tabular}{|l|l|l|l|l|l|l|l|}
\hline \multirow{2}{*}{ Group } & Mean & \multirow{2}{*}{ Std. Deviation } & Skewness & \multicolumn{1}{l|}{ Ratio } \\
\cline { 2 - 6 } & Statistic & Std. Error & & Statistics & Std. Error \\
\hline High Critical Thinkers & 11.52 & 0.39 & 1.87 & 0.41 & 0.48 & 0.85 \\
\hline Low Critical Thinkers & 9.94 & 0.41 & 1.80 & 0.40 & 0.52 & 0.76 \\
\hline
\end{tabular}

According to Table V, the mean scores of high and low critical thinkers were 11.52 and 9.94. So, it can be concluded that high critical thinkers had a moderately better performance than low critical thinkers on referential questions. Both groups enjoyed homogeneous variances (Levene's $\mathrm{F}=0.046, p=0.831>0.05$ ) (See Table VI). 
TABLE VI.

T-TEST ON THE REFERENTIAL QUESTIONS SCORES OF THE HIGH AND LOW CRITICAL THINKERS

\begin{tabular}{|l|l|l|l|l|l|l|l|l|}
\hline & \multicolumn{5}{|c|}{$\begin{array}{l}\text { Levene's Test for Equality of } \\
\text { Variances }\end{array}$} & \multicolumn{5}{|l|}{ t-test for Equality of Means } \\
\cline { 2 - 7 } & $\mathrm{F}$ & Sig. & t & df & Sig. (2-tailed) & Mean Difference & Std. Error Difference \\
\hline $\begin{array}{l}\text { Equal variances assumed } \\
\text { Equal variances not assumed }\end{array}$ & 0.046 & 0.831 & 2.747 & 40 & 0.009 & 1.57437 & 0.57308 \\
& & & 2.757 & 39.023 & 0.009 & 1.57437 & 0.57096 \\
\hline
\end{tabular}

According to the results $(\mathrm{t}=2.747, \mathrm{df}=40, p=0.009<0.05)$ the second null hypothesis was rejected. So, there is a significant difference between the mean scores of referential questions in high and low critical thinkers. The effect size, computed by Cohen's d is 0.86 which corresponds with $r$ value of 0.39 . This indicated a large effect, and therefore, considered as large and strong for the purpose of generalization.

\section{Testing the Third Hypothesis}

In order to test the third hypothesis, i.e." there is no significant difference between high and low critical thinkers on their performance on inferential reading comprehension questions", an independent samples t-test was utilized to compare the mean scores of both groups on inferential questions. TABLE VII, the descriptive statistics of inferential questions, shows the skewness ratio values of -1.37 and 0.51 . Since the ratio values of inferential question scores in both groups are within the acceptable range of \pm 1.96 , normality is assumed and running t-test is confirmed.

TABLE VII.

DESCRIPTIVE STATISTICS OF INFERENTIAL QUESTIONS SCORES

\begin{tabular}{|l|l|l|l|l|l|l|}
\hline \multirow{2}{*}{ Group } & Mean & Std. Deviation & Skewness & \\
\cline { 2 - 5 } & Statistic & Std. Error & & Statistics & Std. Error & Ratio \\
\hline High Critical Thinkers & 11.95 & 0.45 & 2.20 & -0.66 & 0.48 & -1.37 \\
\hline Low Critical Thinkers & 6.52 & 0.57 & 2.50 & 0.27 & 0.52 & 0.51 \\
\hline
\end{tabular}

Before running the t-test, it could be concluded that, on inferential questions, high critical thinkers with the mean score of 11.95 outperformed low critical thinkers with the mean score of 6.52. TABLE VIII displays the results of the independent samples t-test of the inferential questions performance in two groups.

TABLE VIII

T-TEST ON THE INFERENTIAL QUESTIONS SCORES OF THE HIGH AND LOW CRITICAL THINKERS

\begin{tabular}{|c|c|c|c|c|c|c|c|}
\hline & \multicolumn{2}{|c|}{$\begin{array}{l}\text { Levene's Test for Equality of } \\
\text { Variances }\end{array}$} & \multicolumn{5}{|c|}{ t-test for Equality of Means } \\
\hline & $\mathrm{F}$ & Sig. & $\mathrm{t}$ & df & Sig. (2-tailed) & Mean Difference & Std. Error Difference \\
\hline Equal variances assumed & 0.632 & 0.431 & 7.474 & 40 & 0.000 & 5.43021 & 0.72654 \\
\hline Equal variances not assumed & & & 7.383 & 36.280 & 0.000 & 5.43021 & 0.73554 \\
\hline
\end{tabular}

As the above table indicates, the results of the Levene's test $(\mathrm{F}=0.632, p=0.431>0.05)$ revealed that the variances between the two groups are not significantly different and thus, homogeneity of variances is assumed. The probability associated with the $\mathrm{t}$-value $(\mathrm{t}=7.474, \mathrm{df}=40, p=0.000<0.05)$ is lower than 0.05 , therefore, it could be claimed that there is a significant difference between high and low critical thinkers on their performances on inferential reading comprehension questions, meaning that the ability of thinking critically can influence the performance of learners on inferential questions. The effect size computed by Cohen's $\mathrm{d}$ and $\mathrm{r}$ value are 2.36 and 0.76 , respectively. Taking the Cohen's standards into account, the magnitude of findings is large for the purpose of generalization.

\section{DISCUSSION}

The shift from behaviorism to cognitivism in language teaching led to explore the active role of learners in pedagogy. Researchers and teachers focused on learners, their learning styles, learning processes, and cognitive abilities. This might be when the concept of critical thinking attracted great attention. However, the educational systems are still focused on the lower levels of thinking. Consequently, the far-reaching implications of critical thinking in learning process are disregarded. Paul (1993, cited in Cody, 2002) states that" no substantial change can occur in education without a substantial change in the thinking of educators"(p.186). He believes that the educational systems need leaders with the intellectual courage to admit that education is filled with shallow thinking and shallow practices.

The urgent need to teach thinking skills at all levels of education continues (Carr, 1990), therefore, teachers should create an atmosphere of encouragement among the students to read deeply, question, engage in divergent thinking, and look for relationships among ideas. Educators must also replace the idea of "what to think" with "how to think" (Schafersman, 1991; Young, 1992).

The focus of the present study was on the reading comprehension which according to Farhady (1998), in spite of its importance, not much has been done to improve its teaching and testing. 
Many teachers are still practicing reading comprehension through a traditional approach. Reading the passage and answering some factual true/false or factual explanatory questions are all what they do for the purpose of teaching reading comprehension. The same process takes place in exams. But, "teaching for understanding rather than knowledge will bring students to a higher level of learning "(Lord \& Baviskar, 2007, p. 41). With this in mind, teachers should pay more attention to the questions they ask during teaching as well as the exams. Questions should go beyond students' literal knowledge and promote understanding relations and inferring ideas.

The purpose of the current research was to study the concepts of critical thinking and question types. High critical thinkers performed better generally on reading comprehension and specifically on all three types of questions. This could reveal that learners' critical thinking level have influenced their comprehension ability. This is very much in line with Facione's (1992) ideas according to which critical thinking and reading comprehension are significantly correlated and "improvements in the one are paralleled by improvements in the other" (p.21). In spite of the researcher's expectation, the results indicated a significant difference in both groups on all three types of questions. Reviewing the critical thinking definitions, it was expected that high critical thinkers would outperform low critical thinkers just on inferential question. But, the findings proved a better performance of high critical thinkers not only in inferential but also in factual and referential questions. This could have valuable pedagogical implications which are going to be elaborated later. The study has large effect sizes; however, before generalizing the results, more research should be carried out in this regard.

\section{PEDAGOGICAL IMPLICATIONS}

The study showed that critical thinking level of the students played an important role in their reading comprehension ability in general and their performances on different types of questions in particular. The teaching methodologies, in which critical thinking has not reached a status it deserves, can be impacted by the present findings. Looking at teaching from critical thinking angle is a welcome change. Critical thinking can be considered as one of the fundamentals of language teaching. Teachers' experiences show that answering reading comprehension tests are time consuming for almost all learners, but the ability of thinking critically could mitigate the difficulty of taking the reading comprehension test of this study. Therefore, it is strongly suggested to language teachers to use critical thinking strategies, since one of the responsibilities of a good teacher is to teach how to be a better thinker. Challenging topics for class discussions or writing tasks, and asking open-ended questions are easy to apply activities doing a lot to boost critical thinking ability of the students. Task-based language teaching is also very helpful in this regard. Using pre-tasks or post-tasks for the purpose of establishing critical thinking among learners is recommended. In addition, teachers should make use of questions from deeper levels in preference to shallow and literal level. Probably, test designers of TOEFL and IELTS exams also have the same ideology about comprehension. In reading comprehension section of these tests the candidates are expected to answer questions from different levels. A review of TOEFL iBT readings indicates that apart from vocabulary questions, questions about the author's method, purpose and attitude and sentence restatements, candidates should also answer a number of factual, referential, and inferential questions. Therefore, encountering these types of questions during the course creates a chance for learners to tap into different levels of comprehension and be familiar with the types of questions they are supposed to answer in TOEFL or IELTS exams. Preparing lesson plans involving factual, referential, and inferential comprehension questions for each reading material would be very beneficial.

Moreover, abilities of comprehending, analyzing, synthesizing, and evaluating may not be regarded as inherent characteristics of an individual. They must be acquired and practiced. By making use of critical thinking strategies and encouraging deeper understanding, textbook writers can make a very positive contribution in this regard.

The last suggestion addresses test designers. They are encouraged to check critical thinking and reasoning ability of learners instead of their rote memorization.

It seems worthwhile mentioning a point about the importance of factual questions. Although factual questions are categorized as lower order questions, they can be considered as good teaching devices for checking the comprehension ability of elementary learners.

\section{REFERENCES}

[1] Barrett, T. C. (1972). Taxonomy of reading comprehension. Reading 360 Monograph. Lexington, MA: Ginn \& Co.

[2] Bassick, C. Sh. (2008). Improved critical thinking skills as a result of direct instruction and their relationship to academic achievement. Ph.D. dissertation, University of Pennsylvania. http://www.dspace.lib.iup.edu:8080dspace.lib.iup.edu: 8080dspace/bitstream/SherlynnBessick2Corrected.pdf (accessed 15/3/2012).

[3] Been, S. (1975). Reading in the foreign language teaching program. TESOL Quarterly 9.3, 233-242.

[4] Bloom, B. S. (1956). Taxonomy of educational objectives: The classification of educational goals. Boston: Allyn \& Bacon.

[5] Carr. K.S. (1990). How can we teach critical thinking? https://www.ericdigests.org/pre-9218/critical.htm (accessed 4/11/2012).

[6] Carrell, P.L. (1983). Background knowledge in second language comprehension. Language Learning and Communication 2.1, 25-34. 
[7] Carrell, P.L., Devine, J., \& Eskey, E. (1988). Some causes of text-boundedness and schema interference in ESL reading. In P.L. Carrell, J. Devine \& D.E. Eskey (eds), Interactive approaches to second language reading. NY: Cambridge University Press, $101-113$.

[8] Cody, W.K. (2002). Critical thinking and nursing science: Judgment, or vision? Nursing Science Quarterly 15.3, $181-204$.

[9] Cohen, D. A., \& Fine, J. (1978). Reading history in English: Discourse analysis and experience of native and non-native readers. http://www.eric.ed.gov/ERICWebPortal/recordDetailaccnoED165476 (accessed 3/11/2012).

[10] Educational Testing Service. (2004). TOEFL actual tests administered in the past by ETS: 7 full-length paper-based exams for 2002-2004. Tehran: Ebteda publication.

[11] Erten, H. I., \& Karakas, M. (2007). Understanding the divergent influences of reading activities on the comprehension of short stories. The Reading Matrix 7.3, 113-133.

[12] Eskey, D. E., \& Grabe, W. (1988). Interactive models for second language reading: Perspectives on instruction. In P. L. Carrell, J. Devine, \& D. E. Eskey (eds.), Interactive approaches to second language reading. New York: Cambridge University Press, 223-238.

[13] Facione, A. P. (1992). Critical Thinking: What it is and why it counts. http://insightassessment.com/t.html (accessed $16 / 10 / 2011)$.

[14] Faravani, A. (2006). Investigating the effect of reading portfolios on the Iranian students' critical thinking ability, reading comprehension ability, and reading achievement. MA thesis, Ferdowsi University of Mashhad, Iran.

[15] Farhady, H. (1998). Constructing reading comprehension tests. In H. Farhady, Twenty-five years of living with applied linguistics: collection of articles. Tehran: Rahnama Press, 339-369.

[16] Fasko, D. (2003). Critical thinking: origins, historical development, future direction. In D. Fasko (ed.), Critical thinking and reasoning: Current research, theory and practice .Cresskill, NJ: Hampton Press, 3-20.

[17] Grabe, W. (1991). Current developments in second language reading. TESOL Quarterly 25.3, 375-396.

[18] Grabe, W. \& Stoller, L. F. (2002). Teaching and researching reading. Harlow: Pearson Education.

[19] Halonen,J.S. (1995). Demystifying critical thinking. Teaching of Psychology 22.1, 75-81.

[20] Halpern, D.F. (2003).Though and knowledge: An introduction to critical thinking. NJ: Lawrence Erlbaum Associates.

[21] Herber, H. (1978). Teaching reading in content areas (2nd ed.) Englewood Cliffs: Prentice-Hall.

[22] Irwin, J.W. (1986). Teaching reading comprehension process. Englewood Cliffs: Prentice-Hall Inc.

[23] Lehnert, W. (1977). Human and computational question answering. Cognitive Science 1.1, 47-73.

[24] Lord, T., \& Baviskar, S. (2007). Moving students from information recitation to information understanding; Exploiting Bloom's taxonomy in creating science questions. Journal of College Science Teaching 36.5, 40-45.

[25] Mackey, A. \& Gass, S. M. (2005). Second language research: Methodology and design. NJ: Lawrence Erlbaum Association.

[26] Nassaji, H. (2002). Schema theory and knowledge-based processes in second language reading comprehension: A need for alternative perspectives. Language Learning 52.2, 439-481.

[27] Norris, S. \& Ennis, R. (1989). Evaluating critical thinking. Pacific Grove, CA: Thinking Press \&Software.

[28] Pardo, L. S. (2004). What every teacher needs to know about comprehension. The Reading Teacher 58.3, 272-280.

[29] Paul, R., Elder, L., \& Bartell, T. (1997). A brief history of the idea of critical thinking. http://www.criticalthinking.org/ aboutCT/briefHistoryCT.cfm (accessed 10/10/2011).

[30] Pearson, P. D. \& Johnson, D. D. (1978). Teaching reading comprehension. New York: Holt, Rinehart \& Winston.

[31] Rivers, W. M. (1968). Teaching foreign-language skills. Chicago: University of Chicago Press.

[32] Schafersman, D. S. (1991). An introduction to critical thinking. http://www. Freeinquiry.com/ critical-thinking.html (accessed 29/10/2011)

[33] Spolsky, B. (1998). Conditions for second language learning: Introduction to a general theory. NY: Oxford University Press.

[34] Watson, G., \& Glaser, E. (1980). Watson- Glaser critical thinking appraisal. England: The Psychological Corporation.

[35] Watts, G. H. \& Anderson, R.C. (1971). Effects of three types of inserted questions on learning from prose. Journal of Educational Psychology $62.5,387-394$.

[36] Widdowson, H.G. (1979). Explorations in applied linguistics. Oxford: Oxford University Press.

[37] Widdowson, H.G. (1983). Learning purpose and learning use. Oxford: Oxford University Press.

[38] Young, L. E. (1992). Critical thinking skills: Definitions, implications for implementation. Nassp Bulletin 79.3, 47-54.

Samira Mohammadi Forood holds B.A. in English translation and M.A. in Teaching English as a Foreign Language. She has been teaching English in different language institutes. She is currently teaching General English and ESP in Islamic Azad University. Her research interests lie in reading comprehension, ESP, psycholinguistics, and computer assisted language learning.

Ali Akbar Khomeijani Farahani is an Assistant Professor of TEFL at the University of Tehran. He received his B.A. in English Language and Literature from University of Tehran and got his M.A. and Ph.D. in Linguistics from Leeds University. He is teaching linguistics at B.A, M.A, and Ph.D. level at the University of Tehran and Islamic Azad University. His research interests are syntax, discourse analysis, and TBLT, in which he has published quite a few articles. Dr. Khomeijani Farahani is currently a member of the editorial board of a couple of TEFL journals in Iran. 